\title{
Analisis Piutang pada PT. SUCOFINDO (Persero) Cabang Manado
}

\author{
Oleh: \\ Venny Karamoy \\ Grace Bernadette Nangoi \\ Program Pendidikan Profesi Akuntansi
Fakultas Ekonomi dan Bisnis
Universitas Sam Ratulangi Manado
Email: Vny_1511@yahoo.co.id
}

ABSTRAK

Ditengah persaingan bsinis yang ketat, perusahaan dituntut untuk mampu menguasai pasar, sehingga perusahaan perlu melakukan strategi penjualan secara kredit agar jumlah penjualan meningkat. Secara umum, piutang timbul karena adanya transaksi penjualan barang atau jasa secara kredit. Investasi yang terlalu besar dalam piutang bisa menimbulkan lambatnya perputaran modal kerja, sehingga semakin kecil pula kemampuan perusahaan dalam meningkatkan volume penjualan. Akibatnya semakin kecil kesempatan yang dimiliki perusahaan untuk menghasilkan keuntungan atau laba. Tujuan yang diharapkan dapat dicapai dari penelitian ini adalah untuk menganalisis piutang tak tertagih yang dilakukan oleh PT. SUCOFINDO (Persero) Cabang Manado. Adapun metode analisis yang digunakan dalam penelitian ini adalah analisis deskriptif untuk membahas permasalahan yang sifatnya menguraikan, menggambarkan, membandingkan, suatu data atau keadaan, melukiskan dan menerangkan hasil penelitian sehingga dapat ditarik kesimpulan. PT. SUCOFINDO (Persero) Cabang Manado telah melakukan manajemen piutang dan analisis piutang dengan baik. Piutang yang telah jatuh tempo $\leq 90$ hari dan piutang yang berumur 91-360 hari dapat ditagih dengan baik. Sedangkan piutang yang berumur $>1$ tahun dikategorikan sebagai piutang macet yang akan disisihkan menjadi piutang tak tertagih sebesar 55,4\%.

Kata Kunci : Piutang tak tertagih, umur piutang

\section{ABSTRACT}

In the midst of intense business competition, business entity demand to be able to dominate the market, so companies need to do credit sales strategies in order to increase the number of sales. Too much investment in receivable can cause the lower turnover of working capital so company has less ability to increase the sales volume. Consequently, companies have little chance to generate profit or earnings. The objective which expected to be achieved from this research is to analyze the bad debts made by PT. SUCOFINDO (Persero) Manado Branch. The method of analysis that used in this study is descriptive analysis to investigate the issues that explained, described, compared the data or situation, drew and clarified result of the research. PT. SUCOFINDO (Persero) Manado Branch has already used the good management of receivable. The pass due $\leq 90$ days and 91-360 days receivable are classified as collectible accounts receivable. The above 1 (one) year age of receivable categorized as bad debt which estimate uncollectible as $55.4 \%$.

Keywords: Uncollectible receivable, aging period of receivable 


\section{PENDAHULUAN}

\subsection{Latar Belakang Penelitian}

Pada umumnya tujuan suatu perusahaan ditinjau dari sudut pandang ekonomi adalah untuk memperoleh keuntungan (profit oriented), menjaga kelangsungan hidup dan kesinambungan operasi perusahaan, sehingga mampu berkembang menjadi perusahaan yang besar dan tangguh. Kesuksesan perusahaan dalam bisnis hanya bisa dicapai melalui pengelolaan yang baik, khususnya pengelolaan manajemen keuangan sehingga modal yang dimiliki bisa berfungsi sebagaimana mestinya.

Tidak ada satupun perusahaan yang mengharapkan sebagian piutang yang dikeluarkan tidak bisa dibayar oleh debitur walaupun dalam proses pemberian kredit telah diteliti sebaik-baiknya. Namun, pada kenyataannya resiko tak tertagih atas sejumlah piutang pasti akan ditemui.

Untuk mencegah terjadinya penumpukan modal kerja pada piutang tersebut diperlukan suatu sistem akuntansi yang baik dalam pencatatan dan pengelolaan piutang. Pengakuan, penilaian, penyisihan dan penghapusan piutang merupakan seperangkat sistem akuntansi yang harus dijalankan sesuai dengan prosedur untuk mencapai tujuan tersebut.

PT. SUCOFINDO (Persero) adalah perusahaan patungan antara Pemerintah Republik Indonesia dengan Societe Generate de Surveillance Holding SA (SGS), Genewa Swiss yang merupakan perusahaan inspeksi pertama di Indonesia. Bergerak di bidang jasa inspeksi, pengkajian \& pengujian, pelatihan \& konsultasi dan memiliki cabang di hamper seluruh wilayah Indonesia. Salah satu cabang PT. SUCOFINDO (Persero) terletak di Kota Manado. PT. SUCOFINDO (Persero) Cabang Manado juga dalam pelayanan kepada pelanggan memberikan pelayanan jasa secara kredit.

Untuk pengelolaan piutang, dilakukan kebijakan pemberikan kredit kepada pelanggan potensial yang jumlah tagihan atas satu pekerjaan (order) lebih dari Rp. 10 juta. Untuk pelanggan baru dan pelanggan potensial dengan jumlah tagihan tidak lebih dari Rp. 10 juta, maka pembayaran dilakukan tunai $100 \%$ dimuka. Jika tagihan atas pekerjaan lebih dari Rp. 10 juta maka akan dikenakan uang muka sebesar 30\% dari jumlah tagihan ditambah PPN 10\% sementara pelunasan sisa pembayaran

dilakukan pada saat sertifikat/report diserahkan kepada pelanggan. Dengan adanya kebijakan pemberian jasa secara kredit kepada pelanggan, PT. SUCOFINDO (Persero) Cabang Manado juga memiliki resiko sebagian dari penjualan kredit tidak akan tertagih atau bahkan kredit macet. Kerugian yang timbul dari piutang tak tertagih ini diakui sebagai kerugian piutang. Kerugian piutang akan sangat berpengaruh pada laba operasional perusahaan. Dimana semakin besar biaya yang disisihkan untuk kerugian piutang tidak tertagih maka semakin sedikit laba operasional yang didapatkan sementara ekspektasi perusahaan adalah mencari laba sebanyak-banyaknya. Karena dipandang dari berbagai macam aspek, laba yang tinggi akan memberikan keuntungan yang besar untuk perusahaan, pemegang saham dan para pegawainya.

Berdasarkan uraian diatas maka penulis tertarik ingin mengetahui bagaimana prosedur pengelolaan piutang dan analisis piutang yang diterapkan oleh PT. SUCOFINDO (Persero) Cabang Manado mulai dari terjadinya penjualan kredit, pencatatan akuntansi piutang sampai dengan penyisihan dan penghapusbukuan piutang tak tertagih dengan mengangkat judul "Analisis Piutang pada PT. SUCOFINDO (Persero) Cabang Manado."

\subsection{Rumusan Masalah}

Berdasarkan latar belakang yang telah diuraikan, maka rumusan masalah adalah: Bagaimana analisis piutang yang dilakukan oleh PT. SUCOFINDO (Persero) Cabang Manado?

\subsection{Tujuan Penelitian}

Tujuan yang diharapkan dapat dicapai dari penelitian ini adalah untuk menganalisis piutang yang dilakukan oleh PT. SUCOFINDO (Persero) Cabang Manado.

\subsection{Manfaat Penelitian}

Penelitian ini memberi manfaat bagi beberapa pihak, yaitu :

1. Bagi Penulis 
Penelitian ini dapat menambah wawasan bagi penulis mengenai piutang tak tertagih.

2. Bagi Pembaca

Penelitian ini diharapkan dapat menjadi referensi bagi pembaca untuk penelitian selanjutnya.

3. Bagi Perusahaan

Penelitian ini diharapkan dapat menjadi bahan evaluasi PT. SUCOFINDO (Persero) Cabang Manado dalam melakukan pengelolaan piutang.

\section{TINJAUAN PUSTAKA}

\subsection{Akuntansi}

Menurut Sugiarto (2008:5.59) dalam dunia usaha, ilmu akuntansi memegang peranan yang sangat penting dalam menjalankan operasi perusahaan tersebut, apabila ilmu akuntansi pada perusahaan diterapkan dengan baik, maka perusahaan dapat lebih professional dan bijaksana dalam pengambilan keputusan agar keputusan yang diambli benar-benar menunjang keberhasilan usaha. Akuntansi sering disebut sebagai bahasa bisnis atau sering disebut sebagai bahasa dari keputusan keuangan. Hal ini disebabkan oleh karena banyak aspek sehari-hari yang didasarkan pada akuntansi, seperti perencanaan keuangan pribadi, biaya pendidikan, investasi pinjaman, pajak penghasilan dan banyak aspek lainnya.

Horngren dan Harrison (2007:4) menyatakan bahwa : Akuntansi adalah sistem informasi yang mengukur aktivitas bisnis, memproses data menjadi laporan dan mengkomunikasikan hasilnya kepada para pengambil keputusan. Dapat disimbulkan bahwa akuntansi itu adalah sesuatu yang mengukur bisnis, dari mulai penggolongan transaksi dan pengumpulan data lainnya menjadi laporan keuangan, dan setelah selesai menjadi laporan keuangan akan diambil suatu keputusan dari laporan tersebut.

Adapun definisi akuntansi menurut American Institute of Certified Public Accounting (AICPA) yang diterjemahkan oleh Harahap (2011:4), Akuntansi diartikan sebagai proses mengidentifikasikan, mengukur dan menyampaikan informasi ekonomi sebagai suatu beban informasi dalam hal mempertimbangkan berbagai alternatif dalam mengambil keputusan oleh para pemakai.

\subsection{Piutang}

\subsubsection{Pengertian Piutang}

Perusahaan yang berorientasi pada laba tentunya harus memiliki penghasilan. Penghasilan yang diperoleh sesudah dikurangi biaya-biaya akan mendatangkan laba atau rugi yang membawa pengaruh pada jumlah kekayaan perusahaan. Aktivitas utama perusahaan jasa dan dagang adalah menjual jasa atau barang dagangan secara tunai maupun kredit. Penjualan dilakukan secara tunai, langsung mendatangkan uang tunai. Namun penjualan secara kredit, akan mengakibatkan hak penagihan atas piutang. Piutang sendiri timbul dari penjualan barang ataupun jasa karena terdapat kebijakan secara kredit menurut Baridwan (2004:120), yaitu :

1. Pembeli membutuhkan barang dan jasa secara langsung, namun tidak bisa mereka bayar secara langsung atau lebih menyukai untuk membayar secara kredit atau cicil.

2. Penjual dapat menjual lebih banyak dengan melakukan penjualan kredit dibandingkan dengan hanya melakukan penjualan tunai.

Menurut Warren, Reeve, Fess (2005:3), yang diterjemahkan oleh Aria Farahmita, "piutang usaha (account receivable) timbul akibat adanya penjualan kredit. Sebagian besar perusahaan menjual secara kredit agar dapat menjual lebih banyak produk atau jasa. Istilah piutang meliputi semua klaim dalam bentuk uang terhadap entitas lainnya, termasuk individu, perusahaan atau organisasi lainnya."

Dari pengertian diatas dapat disimpulkan bahwa piutang antara lain merupakan semua tuntutan terhadap langganan baik berbentuk perkiraan uang, barang maupun jasa dan segala bentuk perkiraan seperti transaksi. Penjualan secara kredit menimbulkan hak bagi perusahaan melakukan penagihan pada langganannya, dimana hal itu ditentukan oleh persyaratan yang telah disepakati bersama pada saat melakukan transaksi.

\subsubsection{Akuntansi Piutang Usaha}


Akuntansi piutang usaha tetap berpedoman pada sistem akuntansi yang lazim digunakan. Untuk itu setiap transaksi harus dilakukan pencatatan piutang dengan tujuan untuk mencatat mutasi piutang perusahaan kepada setiap debitur. Mutasi piutang ini disebabkan oleh transaksi penjualan kredit, penerimaan pelunasan dari debitur, retur penjualan dan penghapusan piutang. Oleh karena itu setiap diadakabbta transaksi harus disertai bukti-bukti atau dokumen pokok yang digunakan sebagai dasar untuk pencatatan akuntansi.

Transaksi-transaksi tersebut dicatat ke dalam junal sebagai berikut :

a. Transaksi penjualan kredit barang dan jasa kepada pelanggan.

Piutang usaha Penjualan/Pendapatan

b. Transaksi retur penjualan.

Retur Penjualan

Piutang usaha

c. Transaksi penerimaan kas dari debitur.

Kas

Piutang usaha

d. Transaksi penghapusan piutang.

Cadangan kerugian piutang

Piutang usaha $\mathrm{xxx}$

$\operatorname{xxx}$

$\operatorname{xxx}$

$\operatorname{xxx}$

$\mathrm{xxx}$

$\mathrm{xxx}$

XXX

$\mathrm{xxx}$

Dalam melakukan penjualan kredit, perusahaan biasanya memberikan diskon penjualan ataupun diskon dagang. Diskon dagang biasanya dinyatakan dalam persentase, sedangkan diskon penjualan dinyatakan dalam bentuk istilah $2 / 10, \mathrm{n} / 30$ yang artinya diskon $2 \%$ dibayarkan dalam 10 hari, jatuh tempo dalam 30 hari).

Penilaian piutang usaha sedikit lebih kompleks, jumlah piutang yang dinilai dan dilaporkan pada neraca hendaknya menunjukkan jumlah bersih yang diperkirakan akan diterima dalam bentuk kas. Penentuan nilai realisasi bersih (net realizable value) memerlukan estimasi baik atas piutang yang tak tertagih maupun retur dan potongan penjualan.

\subsubsection{Perlakuan Akuntansi Atas Piutang Tak Tertagih}

Menurut Kieso (2008:350) yang diterjemahkan oleh Emill Salim piutang tak tertagih adalah kerugian pendapatan, yang memerlukan, melalui ayat jurnal pencatatan yang tepat pada akun, penurunan aktiva piutang usaha serta penurunan yang berkaitan dengan laba.

Piutang yang telah ditetapkan sebagai piutang tak tertagih bukan merupakan aktiva lagi, oleh karena itu harus dikeluarkan dari pos piutang dalam neraca. Piutang tak tertagih merupakan suatu kerugian, dan kerugian ini harus dicatat sebagai beban (expense), yaitu beban piutang tak tertagih (bad debt expense), yang disajikan dalam laporan laba rugi. Semua penghapusan ini harus dicatat dengan tepat dan teliti karena berhubungan langsung dengan laporan keuangan yang digunakan manajemen dalam pengambilan keputusan.

Ada tiga cara untuk menaksir besarnya cadangan penghapusan piutang, yaitu :

1. Menggunakan analisis umur piutang (aging schedule)

2. Taksiran dari saldo akhir piutang dalam neraca

3. Taksiran dari jumlah selama satu periode.

Menurut Reeve, Warren, dan Fees (2005:321) terdapat metode akuntansi yang diugnakan untuk mencatat piutang tak tertagih :

"There are two methods of accounting for receivables that appear to be uncollectible. The allowance method provides an expense for uncollectible receivable in advance of their write-off. The other procedure, called direct write-off, recognized the expense only when accounting are judge to be worthless." 
Berdasarkan pernyataan diatas, terdapat dua metode akuntansi untuk mencatat piutang tak tertagih, yaitu :

1. Metode Penghapusan Langsung (Direct Write-off Method)

Penggunaan metode ini didasarkan pada adanya indikasi bahwa piutang usaha tidak dapat ditagih lagi dan tidak bernilai lagi. Pencatatan kerugian piutang dilakukan jika ada kepastian bahwa debitur tidak mampu membayar kewajibannya kepada perusahaan.

Kelemahan metode ini adalah tidak dapat dibandingkannya pendapatan dan beban periode yang bersangkutan dengan nilai piutan yang dilaporkan bukan merupakan nilai yang dapat direalisasikan. Ayat jurnal untuk menghapus piutang tak tertagih tersebut adalah :

Untuk menghapus piutang tak tertagih

(D) Beban piutang tak tertagih

$\mathrm{xxx}$

(K) Piutang

Untuk menimbulkan kembali piutang

yang telah dihapus sebelumnya

Untuk mencatat penerimaan kas

(D) Piutang

(K) Beban piutang tak tertagih $\quad \mathrm{xxx}$

(D) Kas/bank

$\mathrm{XXX}$

\section{Metode Penyisihan (Allowance Method)}

(K) Piutang

$\mathrm{xxx}$

Perusahaan-perusahaan besar umumnya menggunakan metode penyisihan ntuk mengestimasi besarnya piutang usaha tidak tertagih. Metode penyisihan mencatat beban atas dasar estimasi dalam periode akuntansi, dimana penjualan kredit dilakukan. Piutang tak tertagih harus dicacat pada periode yang sama seperti penjualan untuk mendapatkan penandingan yang tepat atas beban dan pendapatan serta nilai dari piutang yang tercatat pada neraca merupakan nilai yang dapat direalisasi.

Jurnal-jurnal akuntansi yang berhubungan dengan metode ini adalah sebagai berikut :

Pada saat pembentukan cadangan

(D) Beban piutang tak tertagih $\quad \mathrm{xxx}$

(K) Cadangan Piutang tak tertagih $\quad x x x$

Pada saat penghapusan piutang tak tertagih

Untuk menimbulkan kembali piutang

tak telah dihapuskan

(D) Cadangan Piutang tak tertagih $\mathrm{xxx}$

(K) Piutang

$\mathrm{xxx}$

(D) Piutang

$\mathrm{xxx}$

(K) Cadangan Piutang tak tertagih $\quad x x x$

Untuk mencatat penerimaan kas

(D) Kas/Bank

$\mathrm{xxx}$

(K) Piutang

$\mathrm{xxx}$

Estimasi atas piutang tak tertagih dapat didasarkan pada :

1. Jumlah penjualan, dimana piutang timbul akibat adanya penjualan kredit. Perusahaan dapat menggunakan jumlah penjualan selama satu periode sebagai dasar estimasi piutang tak tertagih dengan persentase tertentu.

2. Jumlah piutang, dimana perusahaan menentukan lamanya waktu piutang usaha tersebut beredar. Untuk itu perusahaan membuat skedul umur piiutang (Aging Schedule). Skedul ini menunjukkan jumlah dan umur piutang.

Menurut Ikatan Akuntan Indonesia, (Pernyataan Standar Akuntansi Keuangan (PSAK) 2002: No. 9, par 7), piutang harus dinyatakan sebesar jumlah kotor tagihan, dikurangi dengan taksiran jumlah yang tidak dapat ditagih. Jumlah kotor piutang harus tetap disajikan pada neraca diikuti dengan penyisihan untuk piutang yang digunakan untuk taksiran jumlah yang tidak dapat ditagih. Dalam PSAK No.9, pencatatan piutang sebagai berikut :

1. Pada saat terjadi penjualan kredit, dicatat dalam jurnal

(D) Piutang dagang

$\mathrm{xxx}$

(K) Penjualan

$\mathrm{xxx}$

2. Pada saat pengakuan kerugian piutang, dicatat dalam jurnal 
(D) Kerugian piutang $\quad \mathrm{xxx}$

(K) Cadangan kerugian $\quad \mathrm{xxx}$

3. Pada saat penghapusan piutang, dicatat dalam jurnal

(D) Cadangan kerugian $\quad \mathrm{xxx}$

(K) Piutang dagang $\quad \mathrm{xxx}$

Jika kerugian piutang ini nanti diakui pada akhir periode, maka diketahui bahwa adanya sejumlah piutang tak tertagih yang didukung oleh data yang akurat yang dihitung oleh bagian akuntansi, maka piutang yang tak tertagih berpengaruh pada total bersih pendapatan perusahaan pada saat itu.

Perusahaan akan memperlakukan biaya kerugian piutang sebagai pendapatan lain-lain, ketika diterima sejumlah uang dari pelanggan yang hutangnya telah dihapuskan pada periode sesudah terjadinya penghapusan piutang. Jika terjadinya pada periode dimana piutang dihapuskan, maka dilakukan dengan mengurangi biaya kerugian piutang.

\subsection{Akuntansi Perusahaan Jasa}

Perusahaan jasa adalah perusahaan yang bergerak dalam penyediaan berbagai pelayanan atau memproduksi produk yang tidak berwujud dengan tujuan mencari laba. Seperti layaknya perusahaan pada umumnya, siklus akuntansi perusahaan jasa diawali dengan terjadinya transaksi, dengan tindak lanjut menganalisis bukti transaksi, mencatat ke dalam jurnal umum, mengelompokkan ke dalam buku besar, merangkum ke dalam neraca saldo, mengikhtisarkan ke dalam kertas kerja, menyajikan dalam laporan keuangan berupa laporan rugi/laba, perubahan modal, neraca dan arus kas.

Tahap-tahap akuntansi adalah prosedur pencatatan transaksi sehingga menjadi laporan keuangan. Hal ini disebut dengan istilah siklus akuntansi. Ada tiga tahap dalam siklus akuntansi yaitu tahap pencatatan (recording phase), tahap pengikhtisaran (summarizing phase) dan tahap pelaporan (reporting phase).

1. Tahap pencatatan (recording phase)

Di dalam akuntansi, bukti transaksi merupakan dokumen sumber dan syarat mutlak dalam melakukan pencatatan transaksi ke dalam jurnal.

Adapun langkah-langkah yang ditempuh dalam tahap pencatatan perusahaan meliputi :

a. Menyiapkan sumber dokumen/bukti transaksi.

b. Dari sumber transaksi tersebut kemudian dilakukan analisa ke jurnal umum.

c. Setelah analisa ke jurnal umum, kemudian diposting kedalam buku besar.

2. Tahap pengikhtisaran (summarizing phase)

Setelah tahap pencatatan diatas telah diselesaikan, maka langkah selanjutnya adalah tahap pengikhtisaran. Adapun urutan dari tahap pengikhtisaran adalah sebagai berikut :

a. Menyusun neraca saldo.

b. Ayat jurnal penyesuaian.

c. Kertas kerja.

d. Jurnal penutup

e. Neraca saldo setelah penutupan.

3. Tahap pelaporan (reporting phase)

Tahap pelaporan ini merupakan tahap yang paling akhir dalam proses akuntansi. Hasil akhir dari proses akuntansi adalah laporan keuangan.

Isi laporan keuangan antara lain :

1. Laporan Rugi Laba (Income Statement)

2. Laporan Perubahan Modal (Capital Statement)

3. Neraca (Balance Sheet)

4. Laporan Arus Kas (Cash Flow) 


\section{METODE PENELITIAN}

\subsection{Jenis dan Sumber Data}

\subsubsection{Jenis Data}

Menurut Arikunto (2006:108), data merupakan keterangan-keterangan yang diperoleh dari sebuah penelitian atau melalui referensi untuk dapat digunakan dalam menganalisis permasalahan yang dihadapi selanjutnya untuk mencari alternatif yang sesuai. Dalam penelitian ini jenis data yang digunakan adalah :

1. Data kualitatif, berupa sejarah singkat perusahaan dan keterangan-keterangan lainnya yang berhubungan dengan perusahaan.

2. Data kuantitatif, merupakan data yang disajikan dalam bentuk angka-angka. Misalnya perhitungan tingkat perputaran piutang, collection period dan perhitungan penyisihan piutang.

\subsubsection{Sumber Data}

Menurut Arikunto (2006:129), sumber data dalam penelitian adalah subjek dari mana data dapat diperoleh. Dalam melakukan pengumpulan data dapat dilakukan dengan dua cara, yaitu dengan metode pengumpulan data primer dan pengumpulan data sekunder.

1. Data primer adalah data yang diperoleh langsung dari perusahaan dengan melakukan wawancara.

2. Data sekunder adalah data yang diperoleh langsung dari perusahaan berupa dokumen-dokumen, laporan-laporan, hasil penelitian, buku-buku, artikel dan berbagai publikasi serta instansi terkait yang relevan dengan masalah.

Dalam penelitian ini sumber data yang penulis peroleh berupa data primer dan data sekunder yang diperoleh dari perusahaan.

\subsection{Metode Analisis Data}

Adapun metode analisis yang digunakan dalam penelitian ini adalah analisis deskriptif untuk membahas permasalahan yang sifatnya menguraikan, menggambarkan, membandingkan, suatu data atau keadaan, melukiskan dan menerangkan hasil penelitian sehingga dapat ditarik kesimpulan. Menurut Sugiono (2009:29) metode deskriptif adalah suatu metode yang berfungsi untuk mendeskripsikan atau memberi gambarn terhadap objek yang diteliti melalui data atau sampel yang telah terkumpul sebagaimana adanya tanpa melakukan analisis dan membuat kesimpulan yang berlaku untuk umum. Dengan kata lain penelitian analisis deskriptif mengambil masalah atau memusatkan perhatian kepada masalah-masalah sebagaimana adanya saat penelitian dilaksanakan, hasil penelitian kemudian diolah dan dianalisis untuk diambil kesimpulannya.

\subsection{Teknik Analisis Data}

Adapun langkah-langkah yang ditempuh dalam menganalisis data yang berkaitan dengan piutang perusahaan sampai pencatatan penyisihan dan penghapusbukuan piutang tak tertagih adalah :

1. Mengumpulkan data-data yang berkaitan dengan terjadinya piutang.

2. Mengevaluasi besarnya jumlah piutang dan besarnya piutang tak tertagih berdasarkan umur piutang.

3. Mempelajari dan mengevaluasi piutang dan kerugian piutang tak tertagih.

4. Berdasarkan hasil analisis diambil kesimpulan dan diberikan saran-saran yang diperlukan.

\section{HASIL PENELITIAN DAN PEMBAHASAN}

\subsection{Hasil Penelitian}

Secara umum proses terjadinya piutang di PT. SUCOFINDO (Persero) Cabang Manado dapat dilihat pada gambar 4.4. 
Gambar 4.4

Prosedur Penerimaan Order

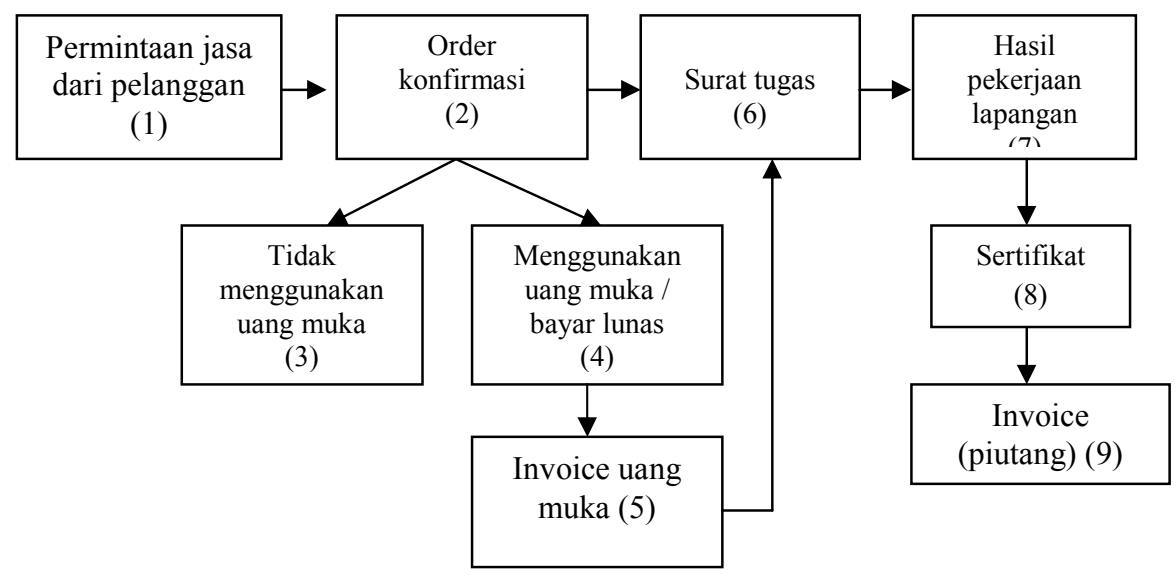

Sumber : PT. SUCOFINDO (Persero) Cabang Manado, 2014

Berdasarkan gambar 4.4 diatas dapat dilihat bahwa piutang pada PT. SUCOFINDO (Persero) itu dimulai dari permintaan jasa dari pelanggan selanjutnya jika telah terjadi kesepakatan mengenai harga dan rencana pelaksanaan kegiatan maka dibuat Order Konfirmasi. Jika harga atas jasa yang telah disepakati nilainya kurang dari 10 juta rupiah, maka harus dibayar tunai oleh pelanggan sebelum pekerjaan dimulai. Jika harga atas jasa yang telah disepakati nilainya lebih dari 10 juta rupiah, maka dibayar dimuka sebesar 30\% sisanya dilunasi setelah sertifikat/report diterima oleh pelanggan. Jika Order Konfirmasi telah disetujui kedua belah pihak, maka PT. SUCOFINDO (Persero) akan menugaskan inspektor untuk melakukan kegiatan survey dengan menerbitkan Surat Tugas. Setelah pekerjaan selesai, inspektor menyerahkan Hasil Pekerjaan Lapangan (HPL) kepada bagian administrasi operasi khususnya petugas pencetak sertifikat untuk dibuat Sertifikat/Report. Berdasarkan nomor Sertifikat/report yang dibuat petugas pencetak sertifikat fungsi Account Receivable (AR) akan membuat invoice/tagihan atas pekerjaan yang telah selesai tersebut. Invoice/tagihan yang telah selesai dibuat, oleh bagian penagihan langsung didistribusikan kepada pelanggan. Untuk ketentuan pembayaran atas piutang pelanggan, PT. SUCOFINDO (Persero) Cabang Manado memberi waktu selama 30 hari. Bagian penagihan melakukan penagihan kepada pelanggan sesuai dengan prosedur pengelolaan piutang yang ada.

Pencatatan akuntansi untuk piutang yang dilakukan oleh PT. SUCOFINDO (Persero) Cabang Manado (dengan asusmsi harga jasa yang akan ditagihkan kepada pelanggan sejumlah 15 juta rupiah belum termasuk PPN 10\%) adalah sebagai berikut :

1. Jika ada uang muka

Pada saat pelanggan melakukan pembayaran uang muka, pencatatan yang dilakukan oleh fungsi AR adalah sebagai berikut :

(D) Bank PHP/MVA Mandiri

Rp. 5.500 .000

(K) PPN

(K) Uang muka Penjualan

Rp. 500.000

Rp. 5.000 .000

Pencatatan ini juga berlaku untuk pembayaran yang dilakukan oleh pelanggan dalam hal pembayaran lunas dimuka sebelum pekerjaan dilakukan. Selanjutnya ketika pekerjaan telah selesai dan diterbitkan sertifikat/report maka akan dibuat invoice/tagihan oleh fungsi AR dengan pencatatan atas pengakuan telah terjadinya piutang sebagai berikut : 
(D) Piutang

(K) PPN

Rp. 16.500 .000

(K) Pendapatan

Rp. $\quad 1.500 .000$

Rp. 15.000 .000

Pada saat pelanggan membayar lunas sisa tagihan, maka fungsi AR melakukan pencatatan sebagai berikut :

(D) Bank PHP/MVA Mandiri

Rp. 11.000 .000

(D) Uang Muka Penjualan

Rp. $\quad 5.000 .000$

(D) $\mathrm{PPN}$

Rp. $\quad 500.000$

(K) Piutang

Rp. 16.500 .000

2. Jika tidak ada uang muka

Jika perusahaan tidak menerima uang muka dari pelanggan, pencatatan yang dilakukan oleh fungsi AR ketika pekerjaan telah selesai dan diterbitkan invoice adalah sebagai berikut :

(D) Piutang

(K) PPN

Rp. 16.500 .000

(K) Pendapatan

Rp. 1.500 .000

Rp. 15.000 .000

Pada saat pelanggan membayar lunas tagihan atas pekerjaan yang telah selesai dan diterbitkan invoice, maka fungsi AR melakukan pencatatan sebagai berikut :

(D) Bank PHP/MVA Mandiri

(K) Piutang
Rp. 16.500 .000

Rp. 16.500 .000

\subsubsection{Timbulnya Piutang}

Dalam pemberikan jasa secara kredit kepada pelanggan, PT. SUCOFINDO (Persero) juga melakukan pertimbangan-pertimbangan dan analisa sehingga harus ada kesepakatan dalam bentuk Order Konfirmasi kepada pelanggan agar PT. SUCOFINDO (Persero) memiliki bukti dan dasar penagihan. Namun pada prakteknya, tidak bisa dihindari adanya suatu resiko dimana timbul piutang tak tertagih. Piutang tak tertagih ini, oleh PT. SUCOFINDO (Persero) Cabang Manado akan dicadangkan sebagai kerugian piutang dan merupakan penambahan atas akun cadangan kerugian piutang.

Pada tabel 4.1 dapat dilihat data yang diperoleh mengenai kondisi piutang PT. SUCOFINDO (Persero) Cabang Manado selama 3 (tiga) tahun terakhir:

\section{Tabel 4.1}

Daftar Piutang PT. SUCOFINDO (Persero) Cabang Manado Periode 2011 - 2013

(dalam rupiah)

\begin{tabular}{|l|l|l|l|}
\hline & $\mathbf{2 0 1 1}$ & $\mathbf{2 0 1 2}$ & $\mathbf{2 0 1 3}$ \\
\hline Pendapatan & 2.229 .458 .990 & 5.734 .416 .415 & 8.442 .891 .217 \\
\hline Piutang & 248.978 .450 & 376.511 .770 & 215.119 .349 \\
\hline
\end{tabular}

Sumber: PT. SUCOFINDO (Persero) Cabang Manado

(Data olahan)

Untuk mendapat gambaran tentang berapa kali (dalam rata-rata) piutang itu terjadi atau timbul dan diterima pembayarannya dalam suatu periode tertentu dapat digunakan rumus rasio Receivable Turn Over (RTO). Periode perputaran atau periode berikutnya modal pada piutang sangat bergantung pada syarat pembarannya. Makin lama syarat pembayarannya berarti makin lama modal terikat dalam piutang. Rumus rasio ini adalah : 
Dimana :

$$
\mathrm{RTO}=\frac{\text { Total Pendapatan }}{\text { Piutang rata-rata }}=\ldots \ldots \ldots \text { Kali }
$$

Piutang rata-rata $=\frac{\text { Piutang periode sebelumnya }+ \text { Piutang selama satu periode }}{2}$

Adapun perhitungan RTO untuk data yang ditampilkan pada tabel 4.1 tahun 2012 adalah:

$$
\begin{aligned}
& =\quad \text { Piutang rata-rata }=\frac{\text { Rp. 248.978.450+Rp. 376.511.770 }}{2} \\
& \text { Rp. 312.745.111,5 }
\end{aligned}
$$

$$
\mathrm{RTO}=\frac{\text { Rp. } 5 \cdot 734 \cdot 416 \cdot 415}{\text { Rp. } 312 \cdot 745 \cdot 111,5}=18,33 \text { Kali }
$$

Hasil perhitungan RTO tahun 2012 menunjukkan bahwa rata-rata piutang terjadi di PT. SUCFINDO (Persero) Cabang Manado adalah sebanyak 18,33 kali. Harapan perusahaan, piutang terjadi setiap bulan sehingga dalam 1 tahun terjadi sebanyak 12 kali. Hal ini berarti bahwa tingkat perputaran piutang di PT. SUCOFINDO (Persero) Cabang Manado dalam periode tahun 2012 tidak mencapai target yang diharapkan yaitu sebanyak 12 kali.

Selanjutnya, perhitungan RTO untuk data yang ditampilkan pada tabel 4.1 tahun 2013 adalah:

$$
\begin{aligned}
& \text { Piutang rata-rata }=\frac{\text { Rp. 376.511.770+Rp. 215.119.349 }}{2} \\
& =\quad \text { Rp. 295.815.559,5 }
\end{aligned}
$$

$$
\mathrm{RTO}=\frac{\text { Rp. } 8 \cdot 442 \cdot 891 \cdot 217}{\operatorname{Rp} .295 \cdot 815 \cdot 559,5}=28,54 \text { Kali }
$$

Hasil perhitungan RTO tahun 2013 menunjukkan bahwa rata-rata piutang terjadi di PT. SUCFINDO (Persero) Cabang Manado lebih besar dari tahun 2012 yaitu sebanyak 28,54 kali. Hal ini berarti bahwa tingkat perputaran piutang di PT. SUCOFINDO (Persero) Cabang Manado dalam periode tahun 2013 tidak mencapai target yang diharapkan yaitu sebanyak 12 kali.

Selanjutnya, untuk dapat mengetahui jangka waktu yang diperlukan untuk mengumpulkan piutang menjadi kas, PT. SUCOFINDO (Persero) dalam kebijakan akuntansinya menggunakan rumus Collection Period. Waktu perputaran piutang dinyatakan dalam hari, hal ini disebabkan syarat pembayaran yang ditetapkan di dalam transaksi penjualan dinyatakan dalam satuan hari sebagai satuan waktu. Rumusnya yaitu :

$\mathrm{CP}=\frac{365}{\mathrm{RTO}}=\ldots \ldots \ldots$. Hari

Adapun perhitungan Collection Period untuk data yang ditampilkan pada tabel 4.1 tahun 2012 adalah sebagai berikut :

$\mathrm{CP}=\frac{365}{18,33}=20$ Hari

Hasil perhitungan Collection Period tahun 2012 menunjukkan bahwa pengumpulan piutang sampai menjadi kas oleh bagian penagihan dapat dicapai dalam waktu 20 hari. Harapan perusahaan terhadap pengembalian piutang menjadi kas adalah 30 hari sesuai dengan ketentuan pelunasan piutang paling 
lambat 30 hari setelah invoice diterima oleh pelanggan. Hal ini berarti, bagian penagihan PT. SUCOFINDO (Persero) Cabang Manado telah bekerja dengan baik sehingga Collection Period tahun 2012 lebih cepat dibandingkan dengan target yang diharapkan oleh perusahaan.

Selanjutnya, perhitungan Collection Period untuk data yang ditampilkan pada tabel 4.1 tahun 2013 adalah sebagai berikut :

$\mathrm{CP}=\frac{365}{28,54}=13$ Hari

Hasil perhitungan Collection Period tahun 2013 menunjukkan bahwa pengumpulan piutang sampai menjadi kas oleh bagian penagihan dapat dicapai dalam waktu 13 hari. Di tahun 2013 pencapaian Collection Period lebih kecil dari pencapaian tahun 2012. Hal ini berarti pencapaian di tahun 2013 lebih baik dari tahun 2012 .

\subsubsection{Prosedur Penagihan Piutang}

Sesuai dengan Keputusan Direksi Nomor 20/KD/2010 tentang Prosedur Pengelolaan Piutang Usaha PT. SUCOFINDO (Persero) tanggal 1 Oktober 2010, prosedur ini dimulai sejak invoice diterima oleh pelanggan, kemudian oleh kolektor dibuat rencana penagihan dan kegiatan telecollection.

\subsubsection{Prosedur Evaluasi Penagihan Piutang}

Sesuai dengan Keputusan Direksi Nomor 20/KD/2010 tentang Prosedur Pengelolaan Piutang Usaha PT. SUCOFINDO (Persero) tanggal 1 Oktober 2010, prosedur ini mencakup pembahasan dan penyelesaian masalah piutang sampai dengan tindak lanjut dan pelaporan.

\subsubsection{Prosedur Penyelesaian Piutang Macet}

Sesuai dengan Keputusan Direksi Nomor 20/KD/2010 tentang Prosedur Pengelolaan Piutang Usaha PT. SUCOFINDO (Persero) tanggal 1 Oktober 2010, prosedur ini mencakup penyusunan, pengumpulan data piutang macet, penyelesaian melalui Kantor Pelayanan Kekayaan Negara dan Lelang (KPKNL) dan/atau Auditor Independen (AI), usulan penghapusbukuan piutang macet dan pelaksanaan penghapusbukuan piutang.

\subsubsection{Pengakuan dan Penyajian Piutang}

Dalam proses akuntansinya, PT. SUCOFINDO (Persero) mengacu pada Standar Akuntansi berlaku yang berlaku umum dan PSAK dan telah menciptakan SOP Akuntansi yang diterapkan di Pusat dan Cabang-cabang termasuk Cabang Manado. Dasar akuntansi yang digunakan adalah metode accrual basic.

Piutang disajikan dalam laporan keuangan sebesar nilai yang diharapkan dapat ditagih atau sebesar piutang usaha bruto dikurangi dengan penyisihan piutang usaha. Adapun bentuk neraca yang digunakan oleh PT. SUCOFINDO (Persero) Cabang Manado, dapat dilihat pada tabel berikut.

Tabel 4.2

Neraca PT. SUCOFINDO (Persero) Cabang Manado

\begin{tabular}{|l|l|l|l|l|l|}
\hline AKTIVA & & & KEWAJIBAN \& EKUITAS & & \\
& & & KEWAJIBAN & & \\
Aktiva Lancar & & $\mathrm{xxx}$ & $\begin{array}{l}\text { Kewajiban Jangka Pendek } \\
\text { Hutang Usaha }\end{array}$ & & \\
Kas & & $\mathrm{xxx}$ & Hutang Pihak Afiliasi & $\mathrm{xxx}$ & \\
Bank & $\mathrm{xxx}$ & Pinjaman Jangka Pendek & $\mathrm{xxx}$ & \\
Deposito Berjangka & & Pinjaman Jk Panjang JT & $\mathrm{xxx}$ & \\
Investasi jangka & & &
\end{tabular}




\begin{tabular}{|c|c|c|c|c|c|}
\hline pendek/ & & $\mathrm{xxx}$ & Wesel bayar & $\mathrm{XxX}$ & \\
\hline Surat berharga & & $\mathrm{xxx}$ & Uang Muka Penjualan & $\mathrm{xxx}$ & \\
\hline Piutang Usaha & $\mathrm{xxx}$ & & Hutang Asuransi & $\mathrm{xxx}$ & \\
\hline Penyisihan Piutang & & & Hutang Pajak & $\mathrm{xxx}$ & \\
\hline Usaha & $(\mathrm{xxx})$ & $\mathrm{xxx}$ & Hutang Lancar Lainnya & $\mathrm{xxx}$ & \\
\hline Pendapatan akan & & $\mathrm{xxx}$ & Pendapatan diterima dimuka & $\mathrm{xxx}$ & \\
\hline diterima & & $\mathrm{xxx}$ & Biaya YMH dibayar & $\mathrm{xxx}$ & \\
\hline Piutang lainnya & & $\mathrm{xxx}$ & Total Kewajiban Jk Pendek & $\underline{\mathrm{xxx}}$ & \\
\hline Uang Muka & & $\mathrm{xxx}$ & & & $\mathbf{X X X}$ \\
\hline Pajak dibayar dimuka & & $\mathrm{xxx}$ & Kewajiban Jangka Panjang & & \\
\hline PPN & & $\mathrm{xxx}$ & Pinjaman jangka panjang & & \\
\hline Biaya dibayar dimuka & & $\underline{\mathrm{xxx}}$ & Hutang surat berharga & $\mathrm{xxx}$ & \\
\hline Total Aktiva Lancar & & $\overline{\mathbf{x x x}}$ & Hutang Jk Panjang lainnya & $\mathrm{xxx}$ & \\
\hline & & & Kewajiban lainnya & $\mathrm{xxx}$ & \\
\hline Aktiva Tidak Lancar & & & Hak Minoritas & $\mathrm{xxx}$ & \\
\hline Investasi jangka & & $\mathrm{xxx}$ & Kewajiban Pajak Tangguhan & $\mathrm{xxx}$ & \\
\hline panjang & & $\mathrm{xxx}$ & Total Kewajiban Jk Panjang & $\underline{\mathrm{xxx}}$ & \\
\hline Aktiva pajak tangguhan & & $\underline{\mathrm{xxx}}$ & & & $\mathbf{X X X}$ \\
\hline Total Aktiva Tidak & & & EKUITAS & & \\
\hline Lancar & & $\mathbf{x x x}$ & Modal disetor & $\mathrm{XXX}$ & \\
\hline Aktiva Tetap & & & Selisih penilaian kembali AT & $\mathrm{xxx}$ & \\
\hline Nilai perolehan & $\mathrm{xxx}$ & & Saldo laba/rugi ditahan & $\mathrm{xxx}$ & \\
\hline Akumulasi Penyusutan & $(\mathrm{xxx})$ & & Selisih transaksi laporan & $\mathrm{xxx}$ & \\
\hline Total Aktiva Tetap & & $\underline{\mathbf{x x x}}$ & Cadangan penggunaan & $\mathrm{xxx}$ & \\
\hline & & & Transaksi atas unit kerja/RK & $\mathrm{xxx}$ & \\
\hline & & & Total Ekuitas & $\mathrm{xxx}$ & \\
\hline TOTAL AKTIVA & & $\mathbf{X X X}$ & $\begin{array}{l}\text { TOTAL KEWAJIBAN \& } \\
\text { EKUITAS }\end{array}$ & & $\begin{array}{l}\text { AXA } \\
\text { XXX }\end{array}$ \\
\hline
\end{tabular}

Sumber : PT. SUCOFINDO (Persero) Cabang Manado, 2014

\subsection{Pembahasan}

\subsubsection{Analisis Tingkat Perputaran Piutang Usaha}

Dari hasil perhitungan perputaran piutang atau terjadinya piutang dalam satu periode dapat diketahui bagaimana keadaaan tingkat perputaran piutang usaha pada PT. SUCOFINDO (Persero) Cabang Manado. Hasil perhitungan perputaran piutang menunjukkan bahwa tingkat perputaran piutang perusahaan dari tahun ke tahun mengalami naik turun.Semakin cepat syarat pembayaran semakin baik bagi perusahaan, karena semakin cepat modal kerja yang tertanam dalam bentuk piutang kembali menjadi modal atau kas.

\subsubsection{Analisis Collection Period Piutang}

Dalam 2 (dua) tahun terakhir, bagian penagihan PT. SUCOFINDO (Persero) Cabang Manado dapat mengumpulkan piutang sampai menjadi kas dalam waktu 20 hari ke bawah. Lebih kecil dari standar harapan perusahaan atas pengembalian piutang menjadi kas dalam waktu 30 hari. Jumlah collection period yang mencapai 20 hari kebawah tersebut boleh dicapai oleh PT. SUCOFINDO (Persero) Cabang Manado karena ketentuan pembayaran lunas dimuka sebelum pekerjaan dilakukan untuk permintaan jasa senilai dibawah Rp. 10juta dan kebijakan perusahaan membentuk prosedur 
pengelolaan piutang. Kedua langkah tersebut sangat membantu bagian penagihan dalam melakukan komunikasi kepada pelanggan agar dapat melunasi kewajibannya.

\subsubsection{Perlakuan Akuntansi Penyisihan Piutang Usaha dan Penghapusbukuan Piutang Tak Tertagih}

Ketidaktepatan dalam mengestimasi, mengakui dan membebankan kerugian piutang atas piutang tak tertagih oleh perusahaan akan menyebabkan biaya kerugian piutang menjadi semakin besar pengaruhnya terhadap laba perusahaan dan mengakibatkan laporan keuangan menjadi tidak akurat.

Dalam hal perhitungan penyisihan piutang usaha atau pencadangan kerugian piutang, PT. SUCOFINDO (Persero) Cabang Manado menggunakan metode penyisihan/cadangan kerugian piutang.

Berdasarkan kebijakan akuntansi perusahaan, persentase penyisihan piutang usaha berdasarkan umur piutang PT. SUCOFINDO (Persero) adalah sebagai berikut :

Tabel 4.3

Perhitungan Penyisihan Piutang Usaha berdasarkan Umur Piutang

\begin{tabular}{|l|l|l|}
\hline Interval & Kategori & Persentase \\
\hline$\leq 90$ hari & Lancar & $0 \%$ \\
\hline $91-360$ hari & Agak Macet & $0 \%$ \\
\hline$>1$ tahun & Macet & $55,4 \%$ \\
\hline
\end{tabular}

Sumber : PT. SUCOFINDO (Persero) Cabang Manado, 2014

Dari tabel 4.3, dapat dilihat bahwa PT. SUCOFINDO (Persero) Cabang Manado dalam mengestimasi persentase piutang tak tertagih mengkategorikan piutang tersebut macet pada umur piutang diatas satu tahun. Sementara untuk umur piutang 91-360 hari, besarnya piutang tak tertagih masih dianggap 0\%. Hal ini disebabkan karena, PT. SUCOFINDO (Persero) Cabang Manado memiliki prosedur penagihan piutang, prosedur penagihan piutang dan prosedur penyelesaian piutang macet yang diatur dalam Keputusan Direksi yang dirangkum dalam Prosedur Pengelolaan Piutang Usaha PT. SUCOFINDO (Persero). Hal ini juga didukung oleh kebijakan lain mengenai prosedur penerimaan order yang harus disertai dengan uang muka 30\% dari nilai jasa jika nilai dari jasa pekerjaan lebih dari Rp. 10juta dan harus dibayar lunas dimuka jika nilai pekerjaan dibawah Rp. 10juta.

Jumlah penyisihan piutang tak tertagih oleh PT. SUCOFINDO (Persero) Cabang Manado dicatat dalam jurnal sebagai berikut :

(D) Biaya Penyisihan Piutang Usaha xxx

(K) Penyisihan Piutang Usaha $\quad \mathrm{xxx}$

Apabila telah diputuskan untuk melakukan penghapusan piutang tak tertagih, maka akan dicatat dalam jurnal sebagai berikut :

(D) Penyisihan piutang usaha $\quad \mathrm{xxx}$

(K) Piutang usaha $\quad \mathrm{xxx}$

Apabila pada suatu waktu, pelanggan yang piutangnya telah dihapusbukukan menyatakan akan melakukan pelunasan atas kewajibannya, maka akan dicatat dalam jurnal sebagai berikut :

(D) Kas
(K) Pendapatan lain-lain

XXX

Pencatatan penerimaan pelunasan dari pelanggan untuk piutang yang telah dihapusbukukan oleh PT. SUCOFINDO (Persero) sesuai dengan prosedur pengelolaan piutang perusahaan, memiliki perbedaan dengan pencatatan sesuai dengan PSAK karena perusahaan langsung mengakui pembayaran yang diterima dari pelanggan atas piutang yang telah dihapusbukukan sebagai pendapatan lain-lain dan tidak lagi menjurnal balik jumlah piutang yang telah dihapusbukukan. Dalam PSAK piutang yang telah dihapusbukukan yang kemudian oleh pelanggan dinyatakan akan dilunasi harus dijurnal balik dahulu untuk mengakui piutang tersebut ada baru kemudian dilakukan jurnal penerimaan atas kas dan 
dilakukan pengurangan atas piutang yang dijurnal balik pada saat diterima informasi oleh pelanggan akan dilunasi.

(D) Piutang Usaha

(K) Cadangan kerugian piutang

(D) Kas

(K) Piutang Usaha $\mathrm{xxx}$

$\mathrm{xxx}$ $\mathrm{xxx}$

$\mathrm{XXX}$

\section{PENUTUP}

\subsection{Kesimpulan}

Berdasarkan hasil penelitian dan analisis yang dilakukan, maka beberapa hal yang dapat disimpulkan adalah sebagai berikut:

1. Tingkat perputaran piutang PT. SUCOFINDO (Persero) Cabang Manado setiap tahun mengalami penurunan dan tidak mencapai target yang diharapkan perusahaan yaitu sebanyak 12 kali dalam satu tahun.

2. Hasil perhitungan Collection Period PT. SUCOFINDO (Persero) Cabang Manado menunjukkan bahwa bagian penagihan bisa mengumpulkan piutang sampai menjadi kas dalam waktu dibawah 20 hari yaitu diatas target ketentuan syarat pembayaran perusahaan selama 30 hari.

3. Dar hasil perhitungan penyisihan piutang usaha berdasarkan umur piutang, semakin tinggi umur piutang, besarnya kemungkinan jumlah piutang tak tertagih akan semakin besar.

4. PT. SUCOFINDO (Persero) Cabang Manado telah melakukan manajemen piutang dan analisis piutang tak tertagih dengan baik.

5. Piutang yang telah jatuh tempo $\leq 90$ hari dan piutang yang berumur 91-360 hari dapat ditagih dengan baik. Sedangkan piutang yang berumur $>1$ tahun dikategorikan sebagai piutang macet dan akan disisihkan oleh perusahaan menjadi piutang tak tertagih.

6. Perlakuan akuntansi kerugian piutang yang diterapkan oleh PT. SUCOFINDO (Persero) Cabang Manado belum sesuai dengan PSAK No 9, karena dalam pencatatan penerimaan kembali piutang yang telah dihapusbukukan tidak melakukan penjurnalan balik tetapi langsung dicatat sebagai pendapatan lain-lain.

\subsection{Saran}

Berdasarkan hasil penelitian, analisis dan kesimpulan yang telah ditarik, maka kepada PT.SUCOFINDO (Persero) Cabang Manado penulis menyarankan sebagai berikut :

1. Agar pihak perusahaan dapat mempertahankan kinerja yang selama ini sangat baik dalam hal pengelolaan piutang usaha sehingga jumlah piutang tak tertagih tidak berjumlah material dan selanjutnya penyisihan piutang usaha pun hanya akan bersaldo kecil.

2. Agar pihak perusahaan selalu konsisten dalam melaksanakan prosedur penerimaan order dengan uang muka 30\% untuk nilai jasa diatas Rp. 10juta dan pembayaran lunas dimuka sebelum pekerjaan dilaksanakan untuk nilai jasa dibawah Rp. 10jt. Karena cara tersebut adalah cara yang ampuh untuk menghindari terjadinya piutang tak tertagih.

3. Agar bagian penagihan selalu konsisten dalam melaksanakan prosedur penagihan piutang dan prosedur evaluasi penagihan piutang sehingga umur piutang di PT. SUCOFINDO (Persero) Cabang Manado semuanya masuk dalam kategori lancar.

\section{DAFTAR PUSTAKA}

Al Haryono Yusuf, Dasar-Dasar Akuntansi, 2005.

Arikunto, Suharsimo, 2006, Prosedur Penelitian Suatu Pendekatan Praktek, Jakarta, Rineka Cipta.

Baridwan, Zaki, Intermediate Accounting, Edisi 8, BPFE Yogyakarta, 2004.

Charles T. Horngren, Walter T. Harrison, Accounting Volume 2, Edisi Ketujuh, Pearson/Prentice Hall, University of California 2007. 
Charles T. Horngren, Walter T. Harrison, Accounting, Terjemahan Gina Gania dan Danti Pujianti, Volume 1, Edisi Ketujuh, Erlangga, 2007.

Kieso, Donald E, Weygant, Jerry J, dan Warfield, D, Intermediate Accounting. Akuntansi Intermediate, Terjemahan Salim Emil, Edisi Kedua Belas, Erlangga, Jakarta 2008.

Mawitjere, Christine, Y.A, Skripsi, Analisis Piutang Tak Tertagih Berdasarkan Umur Piutang Pada Hotel Berbintang di Kota Manado, Manado, 2006.

Natari, Meylan, Skripsi, Analisis Perlakuan Akuntansi Terhadap Piutang Tak Tertagih Pada PT. SUCOFINDO (Persero) Cabang Manado, Manado 2011.

Robert F. Meigs, Mark Bettner, Walter B. Meigs, Ray Wittington Paperback, Accounting : The Basis for Business Decisions, Group A Problems, Richard D Irwin, Chapters 1-15, Tenth Edition, 1999.

Mulya, Hadri, Memahami Akuntansi Dasar ; Pendekatan Teknis Siklus Akuntansi, Mitra Wacana Media, Jakarta 2008.

Mulyadi, Sistem Akuntansi, Salemba Empat, Jakarta 2008.

Pua, Emil A.J, Skripsi, Studi Penetapan Presentase Piutang Tak Tertagih Berdasarkan Umur Piutang Pada Hotel Berbintang di Kota Manado, Manado 2008.

Purwono, Herry, Dasar-Dasar Perpajakan \& Akuntansi Pajak, Erlangga, 2008.

Riyanto, Bambang, Dasar-Dasar Pembelanjaan Perusahaan, Edisi 4, BPFE Yogyakarta 2011.

Soemarso, S.R, Akuntansi Suatu Pengantar, Buku ke-2, Salemba Empat, Jakarta 2005.

Sofyan, Syarif Harahap, Statement of Basis Accounting Theory (ASOBAT), Edisi Revisi, Rajawali Pers, 2011.

Stice, James D, Earl K, Skousen, K Fred, Intermediate Accounting, Terjemahan Akbar Ali, Edisi 16, Salemba Empat, Jakarta 2009.

Sugiarto, Akuntansi Keuangan Menengah 1, Universitas Terbuka, 2008.

Warren, Reeve and Fees, Accounting, 2005.

Warren, Reeve and Fees, Accounting : Pengantar Akuntansi, Terjemahan Aria Farahmita, Amanugrahani, dan Taufik Hendrawan, Edisi 21, Buku 2, Salemba Empat, Jakarta 2005.

http://pengertianakuntansimenurut10paraahli.blogspot.com/2013_04_01_archive.html 